\section{Color Stability, Surface Roughness and Flexural Strength of an Acrylic Resin Submitted to Simulated Overnight Immersion in Denture Cleansers}

Helena de Freitas Oliveira Paranhos, Amanda Peracini, Marina Xavier Pisani, Viviane de Cássia Oliveira, Raphael Freitas de Souza, Cláudia Helena SilvaLovato
Department of Dental Materials and Prosthodontics, Ribeirão Preto Dental School, USP - University of São Paulo, Ribeirão Preto, SP, Brazil

Correspondence: Profa. Dra. Helena de Freitas Oliveira Paranhos, Avenida do Café, S/N, 14040-904 Ribeirão Preto, SP, Brasil. Tel: $+55-16+3602-$ 4031. e-mail: helenpar@forp.usp.br

\begin{abstract}
This study evaluated color stability, surface roughness and flexural strength of acrylic resin specimens after immersion in alkaline peroxide and alkaline hypochlorite, simulating a period of one and a half year of use of overnight immersion. Sixty disc-shaped (16x4 $\mathrm{mm})$ and 80 rectangular specimens $(65 \times 10 \times 3.3 \mathrm{~mm})$ were prepared from heat-polymerized acrylic resin (Lucitone 550$)$ and distributed into 4 groups $(n=20): C 1$ : without immersion, C2: $8 \mathrm{~h}$ immersion in distilled water; AP: $8 \mathrm{~h}$ immersion in alkaline peroxide effervescent tablet; $\mathrm{SH}: 8 \mathrm{~h}$ immersion in $0.5 \% \mathrm{NaOCl}$ solution. Properties were evaluated at baseline and after the immersion. Color data were also calculated according the National Bureau of Standards (NBS). Results were analyzed statistically by ANOVA and Tukey's HSD test $(\alpha=0.05)$. AP $(2.34 \pm 0.41)$ caused color alteration significantly higher than C2 $(0.39 \pm$ $0.30)$ and $\mathrm{SH}(1.73 \pm 0.52)$. The mean $\Delta \mathrm{E}$ values were classified as indicial for $\mathrm{C} 2(0.36$ $\pm 0.29)$ and noticeable for AP $(2.12 \pm 0.39)$ and $\mathrm{SH}(1.59 \pm 0.48)$. SH $(0.0195 \pm 0.0150)$ caused significantly higher $\triangle \mathrm{Ra}(\mathrm{p}=0.000)$ than the $\mathrm{C} 2(0.0005 \pm 0.0115)$ and PA $(0.0005$ $\pm 0.0157)$ groups. There was no statistically significant difference $(p=0.063)$ among the solutions for flexural strength (C1: $105.43 \pm 14.93$, C2: $100.30 \pm 12.43$, PA: $97.61 \pm 11.09$, $\mathrm{SH}: 95.23 \pm 10.18$ ). In conclusion, overnight immersion in denture cleansing solutions simulating a year and a half of use did not alter the flexural strength of acrylic resin but caused noticeable color alterations, higher for alkaline peroxide. The $0.5 \% \mathrm{NaOCl}$ solution caused increase in surface roughness.
\end{abstract}

Key Words: complete denture, denture cleansers, acrylic resins.

\section{Introduction}

Denture cleansing is an important measure that can prevent cross contamination and contributes to patient's oral health, denture longevity and overall quality of life. Several agents are indicated for denture biofilm removal, classified into mechanical and chemical agents (1). Cleaning by chemical method consists in immersing the denture in solutions with solvent, detergent, antibacterial and antifungal actions, and such solutions can be employed alone or in association with brushing or ultrasonic devices $(2,3)$. There are two main classes of immersion denture cleansers: $\mathrm{NaOCl}$ and alkaline peroxides (4).

$\mathrm{NaOCl}$ has been suggested as an effective hygiene agent (5), acting on the biofilm organic matrix, it is bactericidal and fungicidal as well as a stain remover (6). Alkaline peroxides are constituted by oxidant, effervescent, surface tension reducers and chelating agents (4). These products are presented in powder or tablet forms, which in contact with water become hydrogen peroxide solutions. It is well known in the literature the effectiveness of both denture cleansers; however to be considered ideal for long-term use, these hygiene solutions should not cause any adverse effect in the acrylic resin denture base or acrylic denture teeth $(7,8)$. The physical and mechanical properties of acrylic resins should remain unaltered (7).

One disadvantage of $\mathrm{NaOCl}$ is that, depending on its concentration and the immersion time, it may cause whitening of the acrylic resin $(9,10)$. Regarding peroxides, there have been reports on the occurrence of damage to the acrylic resin (11) and the metallic components of the prosthetic device in the form of surface oxidation (12) and release of ions in the solution (13). Factors such as water temperature, immersion time and following the manufacturer's instructions are considered critical (9).

Color changes and flexural strength of acrylic resins have been investigated $(9,14,15)$, as well as the surface roughness (16), but in short periods of immersion. Paranhos et al. (17) did not find alterations in color, roughness and flexural strength of microwave acrylic resins after immersion in denture cleansers $(\mathrm{NaOCl} 0.5 \%$ and $1 \%$, Clorox/Calgon and water) for 20 min daily for 180 days. In a similar study, Davi et al. (10) evaluated the same properties of microwave acrylic resins after immersion in denture cleansers $(0.5 \% \mathrm{NaOCl}$ and $1 \%$, Clorox/Calgon and water) for $8 \mathrm{~h}$ ("overnight") during 180 days and revealed that only the immersion in $1 \% \mathrm{NaOCl}$ increased 
color alteration and reduced the flexural strength of the specimens. The authors highlighted the importance of evaluating the adverse effects when such solutions are used as daily complete denture cleaning agents, employed for long periods and time of immersion.

In this sense, denture hygiene simulating the overnight immersion ( $8 \mathrm{~h}$ ) represents a common situation for patients, as dentists commonly recommend denture removal during the sleeping period and immersion in solutions in order to relieve the underlying tissues and clean the dentures (18). Therefore, the aim of this study was to evaluate the alterations of color, flexural strength and surface roughness of acrylic resin after immersion in solutions of $\mathrm{NaOCl}$ and alkaline peroxide, simulating an overnight use for one year and a half.

\section{Material and Methods}

\section{Specimen Fabrication}

Two metallic matrices were employed (Workshops for Precision Mechanics - USP, Ribeirão Preto, SP, Brazil): 1. circular, for the analysis of color change ( $16 \mathrm{~mm}$ diameter and $6 \mathrm{~mm}$ thick), and 2. rectangular, for the analysis of surface roughness and flexural strength $(67 \times 12 \times 5.3 \mathrm{~mm})$. The metallic matrices were invested with type III dental stone (Gesso-Rio, Rio Claro, SP, Brazil) and condensation silicone (Zetalabor; Zermack, Rovigo, Italy) in \#6 metallic flasks (MAC Dental Products, São Paulo, SP, Brazil). After the removal of the matrices, Lucitone 550 heat-polymerized acrylic resin (Dentsply Ind. e Com. Ltda., Petrópolis, RJ, Brazil) was manipulated, packed, pressed (Protecni Hydraulic Press, Araraquara, SP, Brazil) into the mold and polymerized according to the manufacturer's instructions (water immersion at $73^{\circ} \mathrm{C}$ for 90 min and boiling for $30 \mathrm{~min}$ ), in an electric thermopolymerizing device (Thermocycler T100, Ribeirão Preto, SP, Brazil).

The excess of polymerized resin was cut off with tungsten carbide drill (Labordental, São Paulo, SP, Brazil) using low speed micromotor (Dabi Atlante, Ribeirão Preto, $\mathrm{SP}$, Brazil). Both flat sides of each specimen were polished in the horizontal lathe spindle (DP 9; Struers, Copenhagen, Denmark) with 180-, 320-, 400-, 600-, 1200-grit silicon carbide paper (Norton Abrasives, Guarulhos, SP, Brazil). On one of the flat faces of each specimen, the polishing was performed with a polishing cloth and white of Spain at low speed in the horizontal lathe spindle. After polishing, the final dimensions of circular and rectangular specimens were checked with a CD-6 CSX-B digital caliper (Mitutoyo, Tokyo, Japan).

The circular specimens received two markings with 701 metallic bur (Labordental) on the lateral side, one for identification and another as reference for color measurement. The rectangular specimens received an identification number on the unpolished face. Considering the faces (width and length) of the rectangle, four marks with graphite pencil were made: one in half of the width of the rectangular specimen and 3 on the length. The first mark in half the distance of its length and the other two $1 \mathrm{~mm}$ drawn apart laterally to the first. Connecting these points in an area on the polished surface of the specimen, roughness was measured. After the markings, the specimens were stored in distilled water at $37^{\circ} \mathrm{C}$ for $50 \pm 2 \mathrm{~h}$, to eliminate the residual monomer (14). Sixty disc-shaped samples were obtained for color alteration analyses and 80 rectangular specimens for surface roughness and flexural strength assays.

\section{Immersion Procedures}

The specimens were distributed into the following groups $(n=20)$ : $C 1$ (Control 1): no immersion; $C 2$ (Control 2): Immersion for $8 \mathrm{~h}$ in container with $200 \mathrm{~mL}$ distilled water; AP (Experimental 1): Immersion for $8 \mathrm{~h}$ in container with $200 \mathrm{~mL}$ warm water and one Effervescent Alkaline Peroxide Tablet (Corega Tabs; GlaxoSmithKline, Brentford, Middlesex, United Kingdom); SH (Experimental 2): Immersion for $8 \mathrm{~h}$ in container with $200 \mathrm{~mL}$ of $0.5 \% \mathrm{NaOCl}$ solution (Injectcenter, Ribeirão Preto, SP, Brazil).

The immersions were made to simulate daily hygiene routine for one and a half year (548 days). As the aim was to simulate the nocturnal immersion ("overnight"), each $24 \mathrm{~h}$ corresponded to 3 immersions of $8 \mathrm{~h}$ per day. For this reason, the specimens were immersed for 182 continuous days. The temperatures used were those recommended by the manufacturer for alkaline peroxide (lukewarm water $30 \pm 2^{\circ} \mathrm{C}$ ) and $23 \pm 2^{\circ} \mathrm{C}$ for the $\mathrm{NaOCl}$. The solutions of $\mathrm{NaOCl}$ and alkaline peroxide were changed three times a day. For all groups, after each immersion, the specimens were rinsed in running water for $10 \mathrm{~s}$, dried, immersed in a new solution and the procedure repeated.

The specimens were evaluated for color, surface roughness and flexural strength at baseline and after the cleaning simulation for one and a half year.

\section{Color Alteration Assay}

Group 1 (control) was not employed for color analysis. Other circular specimens were positioned for color measurement with their polished surface facing the opening of the portable colorimeter (Color Guide 45/0; BYK - Gardner, Geretsried, Germany) and their reference markings facing the front of the colorimeter. The color measurements were obtained with the use of CIELab color system, recommended by Commission Internationale de I'Eclairage (CIE) (15). A standardized lighting D65, observation angle of $10^{\circ}$ and light source with visible spectrum (400 to $700 \mathrm{~nm}$ ) was used. The measurement 
geometry was $45 / 0$. The values for $\Delta \mathrm{L}^{*}, \Delta \mathrm{a}^{*}$ and $\Delta \mathrm{b}^{*}$, corresponding to the difference of the values $L^{*}, a^{*}, b^{*}$, respectively, were calculated automatically at baseline and after immersion procedure. The total color alteration $(\Delta E)$ was calculated from the following equation: $\Delta \mathrm{E}^{*}=\left[\left(\Delta \mathrm{L}^{*}\right)^{2}\right.$ $\left.+\left(\Delta \mathrm{a}^{*}\right)^{2}+\left(\Delta \mathrm{b}^{*}\right)^{2}\right]^{1 / 2}$

To relate the color alterations $(\Delta \mathrm{E})$ to the clinical environment, data were quantified by the National Bureau of Standards (NBS) units (18) through the formula: NBS units $=\Delta \mathrm{E} \times 0.92$ and then classified according to the scale: 1) Indicial: $0.0-0.5 ; 2$ ) Slight: $0.5-1.5 ; 3)$ Noticeable: 1.5-3.0; 4) Considerable: $3.0-6.0$; 5) Very: $6.0-12.0$; 6) Excessive: +12.0 .

\section{Surface Roughness}

The surface roughness alteration was evaluated with a Surftest SJ-201P rugosimeter (Mitutoyo, Tokyo, Japan). The specimens were fixed on the rugosimeter measuring table with a double sided tape. For each specimen, three readings were performed $4.0 \mathrm{~mm}$ in length and cutoff value of $0.8 \mathrm{~mm}$ at a speed of $0.5 \mathrm{~mm} / \mathrm{s}$ in the regions corresponding of the marks of the specimens. The roughness of each specimen was calculated by the arithmetic mean of three measurements $(\mu \mathrm{m})$. The alteration in surface roughness ( $\Delta R$ Ra) was obtained by the difference between the roughness after immersion and baseline values.

\section{Flexural Strength}

The flexural strength $(S)$ was measured using a threepoint bending test in a DL 2000 universal testing machine (EMIC, São José dos Pinhais, PR, Brazil) at a crosshead speed of $5 \mathrm{~mm} / \mathrm{min}$. The specimens were subjected to flection until fracture. Three-point bending tests were carried out with a distance of $50 \mathrm{~mm}$ between the two supporting points and a $50 \mathrm{kgf}$ load cell applied to the center of the specimen. Flexural strength was calculated using the formula: $S=3 P L / 2 b d^{2}$, where $S$ is flexural strength, $P$ is the peak load applied, $L$ is the span length, $b$ is the specimen width and $d$ is the specimen thickness. The calculation of the maximum flection of the specimen immediately prior to rupture was done by the tension (T) $x$ deformation (d) curve. The results were expressed in $\mathrm{kgf} / \mathrm{mm}^{2}$ and converted to MPa.

\section{Statistical Analysis}

The statistical tests were performed using the SPSS 12.0 program (SPSS Inc., Chicago, IL, USA). As the distribution was normal, the results of the three assays were compared using one-way ANOVA followed by HSD Tukey's test $(\alpha=0.05)$. The significance level was set at 0.05 .

\section{Results}

Table 1 presents the mean and standard deviation values for color alteration $(\Delta \mathrm{E})$, surface roughness $(\Delta \mathrm{Ra})$ and flexural strength (FS). The difference was significant for color and surface roughness.

Immersion in alkaline peroxide caused significantly higher color alteration, with lower $\Delta \mathrm{E}$ values for Control 2 and intermediate results for $\mathrm{NaOCl}$. The mean $\triangle \mathrm{E}$ values quantified by NBS were classified as 'indicial' (0.36) for the control group and 'noticeable' for the effervescent tablet (2.15) and $\mathrm{NaOCl}$ (1.59).

The $0.5 \% \mathrm{NaOCl}$ increased the surface roughness, as the $\Delta R$ a values obtained in this group were significantly higher than for the other two groups. The statistical analysis showed no significant difference in flexural strength after the simulated period of immersion ( $p=0.063$ ).

\section{Discussion}

The results of the present study showed that overnight immersion for one and a half year in alkaline and hypochlorite solutions caused color alteration in acrylic resin specimens, which were classified as 'noticeable' according to the NBS. The water was employed as control, since it is indicated for complete denture immersion during the sleep period (1).

$\mathrm{NaOCl}$ is an effective method of disinfection (5), being common its indication as denture cleanser and for biofilm control, including for overnight immersion solutions $(1,4)$. However, there is a drawback related to the possibility of whitening the acrylic resin. $(15,17)$.

As a disinfectant agent (short immersions) in relation to color property, the concentration of $\mathrm{NaOCl}$ in the solution is a critical factor to be considered (9), since no change was detected using $0.525 \%$ (15) and 1\% (19) concentrations. For a denture cleanser must be also considered immersion time and period of usage. Paranhos et al. (17), simulating daily immersions of 20 min for 180 days reported no color change of acrylic resins with $0.5 \%$ and $1 \% \mathrm{NaOCl}$ concentrations. In the same period for daily immersions of $8 \mathrm{~h}$, a $1 \% \mathrm{NaOCl}$ solution caused color changes classified

Table 1. Mean and standard deviations of $\Delta \mathrm{E}, \Delta \mathrm{Ra}$ and $\mathrm{FS}$ for the evaluated groups

\begin{tabular}{lccc}
\hline Group & $\Delta \mathrm{E}$ & $\Delta \mathrm{Ra}$ & $\mathrm{FS}$ \\
\hline Control 1 (no immersion) & - & - & $105.43 \pm 14.93$ \\
Control 2 (distilled water) & $0.39 \pm 0.30 \mathrm{a}$ & $-0.0005 \pm 0.1146 \mathrm{a}$ & $100.30 \pm 12.43$ \\
Alkaline peroxide & $2.34 \pm 0.41 \mathrm{~b}$ & $0.0005 \pm 0.1572 \mathrm{a}$ & $97.61 \pm 11.09$ \\
$0.5 \% \mathrm{NaOCl}$ & $1.73 \pm 0.52 \mathrm{c}$ & $0.195 \pm 0.1504 \mathrm{~b}$ & $95.23 \pm 10.18$ \\
\hline
\end{tabular}

Different letters in each column indicate statistically significant difference by the Tukey's test $(p<0.05)$. Absence of lowercase letters among treatments means statistical similarity. 
as "slight" according to the NBS (10). Similar to Hong et al. (20), in the present study, concentration of $0.5 \%$ for $8 \mathrm{~h}$ of immersions caused changes, indicating a trend of increasing $\Delta \mathrm{E}$ values with time.

Alkaline peroxides, as well as the hypochlorite, are indicated for complete denture overnight immersions (1, 4) and may cause color change of acrylic resins, being influenced by the used type of effervescent product $(20,21)$. The results of this study indicated that the changes were higher than those produced by hypochlorite. Corega denture cleanser contains agents releasing oxygen with enzymes, supporting the hypothesis that oxidation in combination with a strong alkaline solution can be deleterious (11).

The $0.5 \% \mathrm{NaOCl}$ caused increase of the acrylic resin surface roughness; however, the obtained results (mean $0.195 \mu \mathrm{m}$ ) were satisfactory, since values below $0.2 \mu \mathrm{m}$ contribute to difficult the biofilm accumulation on the acrylic resin and adhesion of microorganisms (22). Previous studies using concentrations of $0.05 \%(12), 0.5 \%(10,17)$, $1 \%$ (16) and 5.25\% (9) did not indicate changes on the roughness level, disagreeing with the results of this report. However, such studies have used smaller immersion times ( 3 to $20 \mathrm{~min}$ ) and periods of use (4-180 days). The present results indicate that increasing the exposure time to $\mathrm{NaOCl}$ resulted in an increase in surface roughness.

Corega Tabs tablet did not alter the surface roughness, which agrees with the results of Peracini et al. (21), who simulated a usage period of 180 days. However, this result differs from studies with shorter durations and immersion periods $(23,24)$. These differences indicate that for alkaline peroxides, not only the time and immersion period should be considered, but also the type of cleanser.

Even though both products have caused color change, they did not alter the flexural strength of the acrylic resin. In short disinfection simulations, $\mathrm{NaOCl}$ solutions at 1\%, 2.5\% and $5.25 \%$ concentrations did not change this property (25), neither did solutions at $0.5 \%$ and $1 \%$ employed as denture cleansers in daily immersions of 20 min for 180 days (17). However, the current results disagree with the studies that showed changes with hypochlorite (10) and peroxide (21) in immersions for $8 \mathrm{~h}$. These differences may be explained by different methodologies of the studies, such as different concentrations and different times of immersion.

The present study has some methodological limitations; only one type of acrylic resin was evaluated and the oral conditions, such as $\mathrm{pH}$ and biofilm, were not reproduced, which would have some influence on the action of denture cleansers. Also, it was employed one of each type of denture cleanser, one immersion period and one year and half of simulated time of use. Thus, the obtained results alone do not represent clinically significant adverse effects. However, it provided evidence that daily use of $0.5 \% \mathrm{NaOCl}$ can be safe, which must be confirmed by clinical trials.

It was concluded that immersion in denture cleanser solutions (alkaline peroxide and $\mathrm{NaOCl}$ ) simulating overnight use for one and a half year period did not alter the flexural strength of acrylic resin. Color alterations were "noticeable" according to NBS, being more intense for the alkaline peroxide. Immersion in $\mathrm{NaOCl}$ solution caused increase in the surface roughness.

\section{Resumo}

0 estudo avaliou a alteração de cor, rugosidade de superficie e força de flexão de espécimes de resina acrílica após imersão em peróxido alcalino e hipoclorito alcalino, simulando um ano e meio de uso seguindo a imersão noturna. Sessenta espécimes circulares $(16 \times 4 \mathrm{~mm})$ e oitenta retangulares $(65 \times 10 \times 3,3 \mathrm{~mm})$ de resina acrílica termopolimerizável (Lucitone 550) foram distribuídos em 4 grupos $(n=20)$ : $C 1$ : sem imersão, C2: $8 \mathrm{~h}$ de imersão em água destilada; PA: $8 \mathrm{~h}$ de imersão em pastilhas efervescentes de peróxido alcalino; HS: $8 \mathrm{~h}$ de imersão em hipoclorito de sódio a $0,5 \%$. As propriedades foram avaliadas antes e após as imersões. Os dados de alteração de cor também foram calculados de acordo com o National Bureau of Standards (NBS). Os dados foram analisados estatisticamente pelo teste ANOVA e Tukey HSD $(\alpha=0,05)$. 0 PA $(2,34 \pm$ $0,41)$ causou alteração de cor significativamente maior que C2 $(0,39 \pm$ $0,30)$ e $\mathrm{SH}(1,73 \pm 0,2)$. A média $\Delta \mathrm{E}$ foi classificada como indicial para C2 $(0,36 \pm 0,29)$ e perceptivel para PA $(2,12 \pm 0,39)$ e HS $(1,59 \pm 0,48)$. HS $(0,0195 \pm 0,0150)$ causou significantemente maior $\Delta R a(p=0)$ do que os demais (C2: 0,0005 $\pm 0,0115$ e PA: 0,0005 $\pm 0,0157)$. Não houve diferença estatisticamente significante $(p=0,063)$ entre as soluções para a resistência à flexão $(\mathrm{C} 1: 105,43 \pm 14,93 ; \mathrm{C} 2: 100,30 \pm 12,43$, PA: $97,61 \pm$ $11,09, \mathrm{HS}: 95,23 \pm 10,18)$. A imersão noturna em soluções higienizadores de próteses simulando um ano e meio de uso não alterou a resistência à flexão da resina acrílica, porém causou alterações perceptíveis de cor, sendo maiores com o peróxido alcalino. 0 hipoclorito de sódio a 0,5\% causou aumento da rugosidade de superfície.

\section{Acknowledgements}

The authors would like to thank Fundação de Amparo à Pesquisa do Estado de São Paulo - FAPESP (2010/51543-6, 2010/51544-2) for the financial support.

\section{References}

1. Souza RF, Fedorowicz Z, Paranhos HFO, Silva-Lovato $\mathrm{CH}$. Interventions for complete denture cleansing in adults (Protocol for a Cochrane review). Cochrane Database of Systematic Reviews (Online), 2009;4, p.CD007395.

2. Paranhos HF, Silva-Lovato $\mathrm{CH}$, Souza RF, Cruz PC, Freitas $\mathrm{KM}$, Peracini A. Effects of mechanical and chemical methods on denture biofilm accumulation. J Oral Rehabil 2007;34:606-612.

3. Andrade IM, Cruz PC, Silva CH, Souza RF, Paranhos HF, Candido RC, et al.. Effervescent tablets and ultrasonic devices against Candida and mutans streptococci in denture biofilm. Gerodontology 2011;28:264270.

4. Nikawa $\mathrm{H}$, Hamada $\mathrm{T}$, Yamashiro $\mathrm{H}$, Kumagai $\mathrm{H}$. A review of in vitro and in vivo methods to evaluate the efficacy of denture cleansers. Int J ProsthodonT 1999;12:153-159.

5. Orsi IA, Junior AG, Villabona CA, Fernandes FH, Ito IY. Evaluation of the efficacy of chemical disinfectants for disinfection of heat-polymerised acrylic resin. Gerodontology 2011;28:253-257.

6. Jagger DC, Al-Akhazam L, Harrison A, Rees JS. The effectiveness of seven denture cleansers on tea stain removal from PMMA acrylic resin. Int J Prosthodont 2002;15:549-552.

7. Council on Dental Materials, Instruments, and Equipment. Denture 
cleansers. J Am Dent Assoc 1983;106:77-79.

8. Pisani MX, Macedo AP, Paranhos H de F, Silva CH. Effect of experimental Ricinus communis solution for denture cleaning on the properties of acrylic resin teeth. Braz Dent J 2012; 23:15-21.

9. Ma T, Johnson GH, Gordon GE. Effects of chemical disinfectants on the surface characteristics and color of denture resins. J Prosthet Dent 1997;77:197-204.

10. Davi LR, Peracini A, Ribeiro NQ, Soares RB, Silva CH, Paranhos HF, et al.. Effect of the physical properties of acrylic resin of overnight immersion in $\mathrm{NaOCl}$ solution. Gerodontology 2010;27:297-302.

11. Unlü A, Altay OT, Sahmali S. The role of denture cleansers on the whitening of acrylic resins. Int J Prosthodont 1996;9:266-270.

12. Felipucci DNB, Davi LR, Paranhos HFO, Bezzon OL, Silva RF, Pagnano V0. Effect of different cleansers on the surface of removable partial denture. Braz Dent J 2011;22:392-397.

13. Felipucci DNB, Davi LR, Paranhos HFO, Bezzon OL, Silva RF, Barbosa Júnior $F$, et al.. Effect of different cleansers on the weight and ion release of removable partial denture: an in vitro study. J Appl Oral Sci. 2011;19:483-487.

14. Barbosa DB, de Souza RF, Pero AC, Marra J, Compagnoni MA. Flexural strength of acrylic resins polymerized by different cycles. J Appl Oral Sci 2007;15:424-428.

15. Polyzois GL, Yannikakis SA, Zissis AJ, Demetriou PP. Color changes of denture base materials after disinfection and sterilization immersion. Int J Prosthodont 1997; 10:83-89.

16. Azevedo A, Machado AL, Vergani CE, Giampaolo ET, Pavarina AC, Magnani R. Effect of disinfectants on the hardness and roughness of reline acrylic resins. J Prosthodont 2006;15:235-242.

17. Paranhos HF, Davi LR, Peracini A, Soares RB, Lovato CH, Souza RF. Comparison of physical and mechanical properties of microwavepolymerized acrylic resin after disinfection in $\mathrm{NaOCl}$ solutions. Braz Dent J 2009;20:331-335.
18. Zomorodian K, Haghighi NN, Rajaee N, Pakshir K, Tarazooie B, Vojdani $M$, et al.. Assessment of Candida species colonization and denture-related stomatitis in complete denture wearers. Med Mycol 2011;49:208-211.

19. McNeme SJ, von Gonten AS, Woolsey GD. Effects of laboratory disinfecting agents on color stability of denture acrylic resins. J Prosthet Dent 1991;66:132-136.

20. Hong G, Murata H, Li Y, Sadamori S, Hamada T. Influence of denture cleansers on the color stability of three types of denture base acrylic resin. J Prosthet Dent 2009;101:205-213.

21. Peracini A, Davi LR, Ribeiro NQ, Souza RF, Lovato-Silva CH, Paranhos HFO. Effect of denture cleansers on physical properties of heatpolymerized acrylic resin. J Prosthodont Res 2010;54:78-83.

22. Pereira-Cenci $\mathrm{T}$, Cury AA, Cenci MS, Rodrigues-Garcia RC. In vitro Candida colonization on acrylic resins and denture liners: influence of surface free energy, roughness, saliva, and adhering bacteria. Int J Prosthodont 2007;20:308-310.

23. Machado AL, Breeding LC, Vergani CE, da Cruz Perez LE. Hardness and surface roughness of reline and denture base acrylic resins after repeated disinfection procedures. J Prosthet Dent 2009;102:115-122.

24. Silva FC, Kimpara ET, Mancini MN, Balducci I, Jorge AO, Koga-Ito CY. Effectiveness of six different disinfectants on removing five microbial species and effects on the topographic characteristics of acrylic resin. J Prosthodont 2008;17:627-633.

25. Pavarina $A C$, Machado AL, Giampaolo ET, Vergani CE. Effects of chemical disinfectants on the transverse strength of denture base acrylic resins. J Oral Rehabil 2003;30:1085108-109.

Received December 19, 2012 Accepted April 2, 2013 